九州大学学術情報リポジトリ

Kyushu University Institutional Repository

\title{
Requirement of Tiger Puffer Takifugu rubripes for Dietary Iron
}

\section{Zibdeh, Mohammad}

Laboratory of Fish Production Technology, Division of Fish Production Technology, Department of Animal and Marine Bioresource Science, Graduate School of Bioresource and Bioenvironmental Sciences, Kyushu University

Matsui, Seiichi

Laboratory of Fish Production Technology, Division of Fish Production Technology, Department of Animal and Marine Bioresource Science, Faculty of Agriculture, Kyushu University

\section{Furuichi, Masayuki}

Laboratory of Fish Production Technology, Division of Fish Production Technology, Department of Animal and Marine Bioresource Science, Faculty of Agriculture, Kyushu University

https://doi.org/10.5109/24397

出版情報: 九州大学大学院農学研究院紀要. 45 (2)，pp.473-479，2001-02-28. Kyushu University バージョン：

権利関係 : 


\title{
Requirement of Tiger Puffer Takifugu rubripes for Dietary Iron
}

\author{
Mohammad Zibdeh*, Seiichi Matsui and Masayuki Furuichi \\ Laboratory of Fish Production Technology, Division of Fish Production Technology, \\ Department of Animal and Marine Bioresource Science, Faculty of Agriculture, \\ Kyushu University, Fukuoka 812-8581, Japan \\ (Received October 30, 2000 and accepted November 10, 2000)
}

\begin{abstract}
Two experiments were conducted to determine the dietary iron ( $\mathrm{Fe}$ ) requirement of tiger puffer at a water temperarure of $19-29.5^{\circ} \mathrm{C}$. In experiment I, the fish with average body weight of $2.5 \mathrm{~g}$ were fed the purified diets with and without $\mathrm{Fe}$ supplement for 12 weeks. Growth, $\mathrm{Ht}$ value and $\mathrm{Hb}$ content were significantly low in fish fed the diet without $\mathrm{Fe}$ supplement. Reduced values of Fe contents of plasma and vertebrae were also observed in fish fed the Fe-unsupplemented diet. On the other hand, unsaturated iron binding capacity (UIBC) of plasma was higher in fish fed the Fe-unsupplemented diet. In experiment II, the fish averaging $10.9 \mathrm{~g}$ were fed the five diets with different levels of $\mathrm{Fe}(55,92,140,197$ and $263 \mathrm{mg} / \mathrm{kg}$ diet $)$ for 13 weeks. No substantial effect on growth performance was observed in all the groups fed the diets with different Fe levels. However, hematological charateristics and Fe contents of vertebrae and liver were significantly different between the fish fed the diet containing $55 \mathrm{mg}$ $\mathrm{Fe} / \mathrm{kg}$ and other groups. These results suggest that Fe deficiency developes hypochromemia in tiger puffer and the dietary Fe requirement is $90-140 \mathrm{mg} / \mathrm{kg}$ diet.
\end{abstract}

\section{INTRODUCTION}

Iron $(\mathrm{Fe})$ is one of the essential minerals that fishes require in diets. Studies on mineral requirements of fishes have indicated that dietary iron deficidency causes anaemic symptoms such as microcytic hypochromemia and the anisocytosis of erythrocyte, and taht its requirements are in the range of 30-170 mg per kg diet in most of fishes (Arai et al., 1975; Sakamoto and Yone, 1978a; Gatlin and Wilson, 1986; Iida et al., 1991; Anderson et al., 1996). However, there are only a few reports with marine fishes. The present study was conducted to determine the dietary Fe requirement of tiger puffer, which is one of the important marine culture species in Japan.

\section{MATERIALS AND METHODS}

\section{Experimental Diets}

Compositions of the experimental diets are shown in Table 1. Two experiments were conducted. Protein source was 55\% vitamin-free milk casein in experiment I and $45 \%$ vitamin-free milk casein and $10 \%$ squid meal in experiment II. In experiment I, two diets were prepared by adding mineral mixtures with and without iron ( $\mathrm{Fe}$ ) supplement from

\footnotetext{
* Laboratory of Fish Production Technology, Division of Fish Production Technology, Department of Animal and Marine Bioresource Science, Graduate School of Bioresource and Bioenvironmental Sciences, Kyushu University. Present address: Marine Science Station, University of Jordan, PO Box 195, Aqaba, Jordan.
} 
Table 1. Compositions of the experimental diets for tiger puffer

\begin{tabular}{|c|c|c|c|c|c|c|c|}
\hline \multirow{2}{*}{$\begin{array}{l}\text { Experiment } \\
\text { Diet no. }\end{array}$} & \multicolumn{2}{|c|}{ I } & \multicolumn{5}{|c|}{ II } \\
\hline & 1 & 2 & 3 & 4 & 5 & 6 & 7 \\
\hline $\begin{array}{l}\text { Supplemental Fe } \\
\text { (mg/kg diet) }\end{array}$ & 200 & 0 & 0 & 75 & 125 & 150 & 200 \\
\hline Dietary Fe (mg/kg) & 220 & 19 & 55 & 92 & 140 & 197 & 263 \\
\hline \multicolumn{8}{|l|}{ Ingredient(\%) } \\
\hline Casein ${ }^{* 1}$ & 55 & 55 & 45 & 45 & 45 & 45 & 45 \\
\hline Squid meal & 0 & 0 & 10 & 10 & 10 & 10 & 10 \\
\hline Dextrin & 10 & 10 & 10 & 10 & 10 & 10 & 10 \\
\hline$\alpha-$ Starch & 5 & 5 & 5 & 5 & 5 & 5 & 5 \\
\hline Pollack liver oil & 10 & 10 & 10 & 10 & 10 & 10 & 10 \\
\hline Vitamin mix.*2 & 3 & 3 & 3 & 3 & 3 & 3 & 3 \\
\hline Mineral mix.*3 & 8 & 8 & 8 & 8 & 8 & 8 & 8 \\
\hline Fe-citrate & 0.12 & 0 & 0 & 0 & 0 & 0 & 0 \\
\hline Ferrous chloride & 0 & 0 & 0 & 0.027 & 0.044 & 0.053 & 0.071 \\
\hline Guar gum & 3 & 3 & 3 & 3 & 3 & 3 & 3 \\
\hline Feeding stimulant*4 & 2 & 2 & 1 & 1 & 1 & 1 & 1 \\
\hline$\alpha$-Cellulose & 3.88 & 4 & 5 & 4.973 & 4.956 & 4.947 & 4.929 \\
\hline
\end{tabular}

*1 Vitamin-free milk casein.

*2 Vitamin mixture (Halver, 1957).

${ }^{*} \mathrm{Fe}$-free mineral mixture (in $100 \mathrm{~g}$ ): $\mathrm{KCl}, 6.54 ; \mathrm{MgSO}_{4} \cdot 7 \mathrm{H}_{2} \mathrm{O}, 6.82 ; \mathrm{NaH}_{2} \mathrm{PO}_{4} \cdot 2 \mathrm{H}_{2} \mathrm{O}, 25.22 ;$ Ca-lactate, 24.53; cellulose, $36.60(\mathrm{~g}) ; \mathrm{AlCl}_{3} \cdot 6 \mathrm{H}_{2} \mathrm{O}, 8 ; \mathrm{ZnSO}_{4} \cdot 7 \mathrm{H}_{2} \mathrm{O}, 177 ; \mathrm{MnSO}_{4} \cdot 4-6 \mathrm{H}_{2} \mathrm{O}, 40 ; \mathrm{CuCl}, 5 ; \mathrm{KI}, 8 ; \mathrm{CoCl}_{2}$. $6 \mathrm{H}_{2} \mathrm{O}, 52$ (mg).

${ }^{* 4}$ Alanine 0.3 , sodium aspartate 0.3 , sodium glutamate $0.032,5^{\prime}$-ribonucleotide $\cdot \mathrm{Na} 0.368 \mathrm{~g} / \mathrm{g}$.

Fe-citrate. In experiment II, five diets were formulated to contain different levels of dietary Fe from ferrous chloride. The diets were pelleted according to the method as previously reported (El-Zibdeh et al., 1995). The Fe contents of diets (1 and 2) with and without Fe supplement in experiment I were 220 and $19 \mathrm{mg} / \mathrm{kg}$, and those of diets 3 to 7 in experiment II were $55,92,140,197$ and $263 \mathrm{mg} / \mathrm{kg}$, respectively.

\section{Fish and Rearing}

Juvenile tiger puffer (Takifugu mubripes), which were produced from eggs at the Fishery Research Raboratory of Kyushu University, were acclimatized to indoor laboratory conditions for 3 weeks and were sorted into two replicate groups of 30 fish each in experiments I and II. Initial average body weights of fish were $2.5 \mathrm{~g}$ in experiment I and approximately $11 \mathrm{~g}$ in experiment II. The rearing was conducted in $150 \ell$ rectangular flow-through aquaria with a flow rate of approximately $1.5 \mathrm{\ell} / \mathrm{min}$. Water temperarue ranged from 19 to $29.5^{\circ} \mathrm{C}$. The fish were fed each diet three times a day to satiation for 12 weeks in experiment I and 13 weeks in experiment II. Body weight of individual fish was measured at biweekly intervals. Other rearing methods were the same as those described previouly (El-Zibdeh et al., 1995).

\section{Analytical Methods}

At the end of the feeding trials, weight gain, feed efficiency, condition factor and 
hepatosomatic index were measured. Blood samples were taken by cardiac puncture from 10 fish randomly selected from each group. Hemoglobin content, Hematocrit value and plasma protein content were determined by the cyanmethemoglobin method, a Kubota hematocrit reader and an ATAGO serum protein refractometer, respectively. Red blood cells were counted using a hemocytometer (improved Neubauer type). Plasma triglyceride and mineral contents $(\mathrm{P}, \mathrm{Ca}, \mathrm{K}$ and $\mathrm{Mg}$ ) of pooled samples from each group were determined using a Rapid Blood Analyzer (RaBA-Super) and Unikits (Chugai Pharmaceutical Co.). Plasma Fe and unsaturated iron binding capacity (UIBC) were determined by the Nitroso-PSAP method (Fe C-test Wako and UIBC-test Wako, Wako Pure Chemicals Co.). A composite sample of liver and vertebrae from each group was subjected to proximate composition and mineral analyses. Mineral contents of the samples were determined with a Perkin-Elmer 3000 atomic absorption spectrophotometer (Perkin-EImer Co., USA) except that $\mathrm{P}$ was measured by the molybdenate blue method.

\section{Statistical Analysis}

Student's T-test was employed to determine the significance in difference between the treatment means in growth, hepatosomatic index and condition factor data. Hematological data were subjected to analysis of variance, and significance of difference $(P<0.05)$ was determined by the Fisher's PLSD test.

\section{RESULTS}

\section{Experiment I}

Tiger puffer fed the diet without Fe supplement manifested significantly reduced growth compared to the control group while feed efficiency was comparable to each other (Table 2). Distinguishable pale yellow color of the liver and significantly low hepatosomatic index were also observed in the Fe-unsupplemented group. However, no effect was observed on the condition factor. Significantly reduced values of $\mathrm{Ht}, \mathrm{Hb}$, and plasma total protein were observed in fish fed the Fe-unsupplemented diet (Table 3). Plasma Fe

Table 2. Effect of dietary Fe supplement on growth performance of tiger puffer (Expt. I)

\begin{tabular}{|c|c|c|}
\hline Diet no. & $\begin{array}{c}1 \\
\text { (Cont.) }\end{array}$ & $\begin{array}{c}2 \\
(-\mathrm{Fe})\end{array}$ \\
\hline \multicolumn{3}{|l|}{ Average body weight (g) } \\
\hline Initial & $2.5 \pm 0.2$ & $2.5 \pm 0.2$ \\
\hline Final $^{* 1}$ & $33.9 \pm 4.5^{\mathrm{a}}$ & $27.4 \pm 4.7^{\mathrm{b}}$ \\
\hline Average weight gain (\%) & 1124 & 994 \\
\hline Feed efficiency $(\%) * 2$ & 76 & 74 \\
\hline Condition factor*3 & $3.23 \pm 0.19$ & $3.01 \pm 0.11$ \\
\hline Hepatosomatic index ${ }^{* 4}$ & $8.24 \pm 0.36^{\mathrm{a}}$ & $6.29 \pm 0.58^{\mathrm{b}}$ \\
\hline
\end{tabular}


Table 3. Effect of dietary Fe supplement on blood profile of tiger puffer (Expt. I)

\begin{tabular}{llcc}
\hline Diet no. & & $\begin{array}{c}1 \\
\text { (Cont) }\end{array}$ & $\begin{array}{c}2 \\
(-\mathrm{Fe})\end{array}$ \\
\hline $\mathrm{Ht}$ & $(\%)^{* 1}$ & $12.4 \pm 1.7^{\mathrm{a}}$ & $3.3 \pm 0.4 \mathrm{~b}$ \\
$\mathrm{Hb}$ & $(\mathrm{g} / 100 \mathrm{ml})$ & $3.6 \pm 0.4^{\mathrm{a}}$ & $1.2 \pm 0.4 \mathrm{~b}$ \\
Total protein & $(\mathrm{g} / 100 \mathrm{ml})$ & $3.3 \pm 0.3^{\mathrm{a}}$ & $2.6 \pm 0.1 \mathrm{~b}$ \\
Triglyceride & $(\mathrm{mg} / 100 \mathrm{ml})$ & 137 & 135 \\
$\mathrm{P}$ & $(\mathrm{mg} / 100 \mathrm{ml})$ & 11.4 & 8.0 \\
$\mathrm{Ca}$ & $(\mathrm{mg} / 100 \mathrm{ml})$ & 11.3 & 9.7 \\
$\mathrm{Mg}$ & $(\mathrm{mg} / 100 \mathrm{ml})$ & 2.6 & 1.8 \\
$\mathrm{Fe}$ & $(\mu \mathrm{g} / 100 \mathrm{ml})$ & 72 & 28 \\
UiBC & $(\mu \mathrm{g} / 100 \mathrm{ml})^{* 2}$ & 229 & 412 \\
\hline
\end{tabular}

*1 Values in the same row with different superscript letters are significantly different $(P<0.05)$.

*2 Unsaturated iron binding capacity.

Table 4. Effect of dietary Fe supplement on mineral contents of the vertebrae of tiger puffer (Expt. I)*

\begin{tabular}{llcc}
\hline \multicolumn{2}{l}{ Diet no. } & $\begin{array}{c}1 \\
\text { (Cont.) }\end{array}$ & $\begin{array}{c}2 \\
(-\mathrm{Fe})\end{array}$ \\
\hline $\mathrm{Ca}(\%)$ & 28.1 & 28.2 \\
$\mathrm{P}$ & $(\%)$ & 10 & 9.9 \\
$\mathrm{Mg}$ & $(\%)$ & 0.36 & 0.38 \\
$\mathrm{~K}$ & $(\%)$ & 0.04 & 0.05 \\
$\mathrm{Fe}$ & $(\mu \mathrm{g} / \mathrm{g})$ & 22.2 & 4.6 \\
$\mathrm{Zn}(\mu \mathrm{g} / \mathrm{g})$ & 77.2 & 75.3 \\
$\mathrm{Mn}(\mu \mathrm{g} / \mathrm{g})$ & 24.0 & 36.3 \\
$\mathrm{Cu}(\mu \mathrm{g} / \mathrm{g})$ & 2.4 & 3.0 \\
\hline
\end{tabular}

* Data are on dry weight basis.

Table 5. Effect of dietary Fe supplement on proximate compositions of the liver of tiger puffer (Expt. I)*

\begin{tabular}{lccc}
\hline Diet no. & & $\begin{array}{c}1 \\
\text { (Cont.) }\end{array}$ & $\begin{array}{c}2 \\
(-\mathrm{Fe})\end{array}$ \\
\hline Moisture & $(\%)$ & 42.7 & 40.7 \\
Crude protein (\%) & 10.8 & 12.3 \\
Crude lipid & $(\%)$ & 84.1 & 82.7 \\
Crude ash & $(\%)$ & 3.0 & 2.8 \\
\hline
\end{tabular}

* Data are on dry weight basis.

content also markedly decreased and UIBC increased in the Fe-unsupplemented group. Furthermore, Fe content of vertabrae was markedly low in the Fe-unsupplemented group (Table 4). On the other hand, no influence of Fe supplementation was observed on proximate compositions of the liver (Table 5). These results indicate that serious anaemic symptoms are developed due to Fe deficiency in tiger puffer.

\section{Experiment II}

No substantial effects on growth, feed efficiency, and condition factor were observed 
Table 6. Effect of dietary Fe levels on growth performance of tiger puffer (Expt. II)

\begin{tabular}{lccccc}
\hline $\begin{array}{l}\text { Diet no. } \\
\text { (Dietary Fe, mg/kg) }\end{array}$ & $\begin{array}{c}3 \\
(55)\end{array}$ & $\begin{array}{c}4 \\
(92)\end{array}$ & $\begin{array}{c}5 \\
(140)\end{array}$ & $\begin{array}{c}6 \\
(197)\end{array}$ & $\begin{array}{c}7 \\
(263)\end{array}$ \\
\hline $\begin{array}{c}\text { Average body wt. (g) } \\
\text { Initial }\end{array}$ & $10.9 \pm 1.6$ & $10.9 \pm 1.7$ & $11.0 \pm 1.7$ & $11.1 \pm 1.6$ & $11.1 \pm 1.6$ \\
$\quad$ Final & $64.9 \pm 13.8$ & $65.6 \pm 14.3$ & $71.1 \pm 18.5$ & $69.1 \pm 13.9$ & $70.2 \pm 16.4$ \\
Average wt. gain (\%) & 492 & 497 & 545 & 522 & 536 \\
Feed efficiency (\%) & 87 & 79 & 79 & 75 & 81 \\
Condition factor* & $3.2 \pm 0.2$ & $3.2 \pm 0.2$ & $3.3 \pm 0.3$ & $3.4 \pm 0.3$ & $3.2 \pm 0.2$ \\
Hepatosomatic index* & $8.1 \pm 1.4$ & $8.3 \pm 0.8$ & $8.9 \pm 1.4$ & $8.8 \pm 1.7$ & $9.0 \pm 1.3$ \\
Mortality (\%) & 21.7 & 11.7 & 12.8 & 14.2 & 8.5 \\
\hline
\end{tabular}

* See Table 2.

Table 7. Effect of dietary Fe levels on hematological characteristics and mineral contents of the plasma of tiger puffer (Expt. II)

\begin{tabular}{|c|c|c|c|c|c|}
\hline $\begin{array}{l}\text { Diet no. } \\
\text { (Dietary Fe, mg/kg) }\end{array}$ & $\begin{array}{c}3 \\
(55) \\
\end{array}$ & $\begin{array}{c}4 \\
(92) \\
\end{array}$ & $\begin{array}{c}5 \\
(140) \\
\end{array}$ & $\begin{array}{c}6 \\
(197) \\
\end{array}$ & $\begin{array}{c}7 \\
(263) \\
\end{array}$ \\
\hline $\mathrm{Ht}(\%)^{* 1}$ & $19.7 \pm 3.8^{\mathrm{b}}$ & $26.1 \pm 2.6^{\mathrm{a}}$ & $27.3 \pm 2.1^{\mathrm{a}}$ & $25.1 \pm 2.7^{\mathrm{a}}$ & $26.5 \pm 1.9^{\mathrm{a}}$ \\
\hline $\mathrm{Hb}(\mathrm{g} / 100 \mathrm{ml})$ & $1.8 \pm 0.9^{b}$ & $3.8 \pm 1.0^{\mathrm{a}}$ & $3.5 \pm 0.6^{\mathrm{a}}$ & $3.7 \pm 0.8^{\mathrm{a}}$ & $4.3 \pm 0.8^{\mathrm{a}}$ \\
\hline $\mathrm{RBC}\left(\times 10^{6} / \mathrm{mm}^{3}\right)$ & $1.25 \pm 0.17^{\mathrm{c}}$ & $2.62 \pm 0.57^{\mathrm{a}}$ & $2.07 \pm 0.42^{\mathrm{b}}$ & $2.16 \pm 0.18^{b}$ & $2.73 \pm 0.58^{a}$ \\
\hline $\mathrm{MCH}(\gamma \gamma)^{* 2}$ & $14.1 \pm 3.9$ & $15.5 \pm 5.4$ & $17.0 \pm 3.3$ & $17.0 \pm 4.7$ & $16.3 \pm 4.7$ \\
\hline $\operatorname{MCV}\left(\mu^{3}\right)^{* 3}$ & $167 \pm 14^{\mathrm{a}}$ & $105 \pm 22^{\mathrm{b}}$ & $137 \pm 37^{\mathrm{ab}}$ & $107 \pm 18^{\mathrm{b}}$ & $103 \pm 14^{\mathrm{b}}$ \\
\hline MCHC (\%) & $7.5 \pm 3.1^{\mathrm{c}}$ & $14.6 \pm 4.3^{\mathrm{ab}}$ & $12.8 \pm 2.1^{\mathrm{b}}$ & $15.3 \pm 3.3^{\mathrm{ab}}$ & $16.0 \pm 2.7^{\mathrm{a}}$ \\
\hline $\mathrm{Ca}(\mathrm{mg} / 100 \mathrm{ml})$ & 10.3 & 11.6 & 12.4 & 10.8 & 10.6 \\
\hline $\mathrm{P}(\mathrm{mg} / 100 \mathrm{ml})$ & 6.1 & 5.4 & 6.5 & 5.4 & 6.1 \\
\hline $\mathrm{Mg}(\mathrm{mg} / 100 \mathrm{ml})$ & 3.0 & 2.3 & 1.9 & 1.8 & 1.9 \\
\hline $\mathrm{K}(\mathrm{mEq} / \mathrm{l})$ & 2.6 & 1.9 & 1.1 & 1.4 & 1.0 \\
\hline $\mathrm{Fe}(\mu \mathrm{g} / 100 \mathrm{ml})$ & 50 & 115 & 109 & 107 & 112 \\
\hline UIBC $(\mu \mathrm{g} / 100 \mathrm{ml})^{* 5}$ & 369 & 274 & 267 & 260 & 256 \\
\hline TIBC $(\mu \mathrm{g} / 100 \mathrm{ml})^{* 6}$ & 419 & 389 & 376 & 367 & 268 \\
\hline ISI $(\%)^{* 7}$ & 11.9 & 29.6 & 28.9 & 29.2 & 30.4 \\
\hline
\end{tabular}

${ }^{* 1}$ Values in the same row with different superscript letters are significantly different $(P<0.05)$.

*2 Mean corpuscular hemoglobin.

*3 Mean corpuscular volume.

*4 Mean corpuscular hemoglobin concentration.

*5 Unsaturated iron binding capacity.

* Total iron binding capacity.

*7 Iron saturation index.

in all the groups fed different levels of Fe supplement (Table 6). Hepatosomatic index increased with increasing levels of dietary $\mathrm{Fe}$, but the significant difference was not recognized among these values. Ht value, $\mathrm{Hb}$ content, and $\mathrm{RBC}$ of fish fed $55 \mathrm{mg} \mathrm{Fe} / \mathrm{kg}$ diet were significantly lower than those of the other groups (Table 7). MCH was also lowest in fish fed $55 \mathrm{mg} \mathrm{Fe} / \mathrm{kg}$ diet, but there were no significant differences among the treatment groups. However, MCV was significantly high and MCHC was significantly low in fish fed the diet containing $55 \mathrm{mg} \mathrm{Fe} / \mathrm{kg}$. The minimum values of plasma $\mathrm{Fe}$ and ISI and 
Table 8. Effect of dietary Fe levels on mineral contents of the vertebrae of tiger puffer (Expt. II)*

\begin{tabular}{|c|c|c|c|c|c|}
\hline $\begin{array}{l}\text { Diet no. } \\
\text { (Dietary Fe, mg/kg) }\end{array}$ & $\begin{array}{c}3 \\
(55) \\
\end{array}$ & $\begin{array}{c}4 \\
(92) \\
\end{array}$ & $\begin{array}{c}5 \\
(140) \\
\end{array}$ & $\begin{array}{c}6 \\
(197) \\
\end{array}$ & $\begin{array}{c}7 \\
(263) \\
\end{array}$ \\
\hline Crude ash (\%) & 56.9 & 56.1 & 56.9 & 58.6 & 57.4 \\
\hline $\mathrm{Ca}(\%)$ & 27.3 & 26.3 & 26.3 & 26.4 & 26.4 \\
\hline $\mathrm{P}(\%)$ & 5.9 & 5.8 & 5.9 & 6.3 & 6.3 \\
\hline $\mathrm{Mg}(\%)$ & 1.3 & 1.3 & 1.1 & 1.4 & 1.3 \\
\hline $\mathrm{Fe}(\mu \mathrm{g} / \mathrm{g})$ & 22.2 & 22.9 & 26.6 & 26.5 & 27.1 \\
\hline $\mathrm{Zn}(\mu \mathrm{g} / \mathrm{g})$ & 51.8 & 51.3 & 61.7 & 60.9 & 60.6 \\
\hline $\mathrm{Mn}(\mu \mathrm{g} / \mathrm{g})$ & 17.1 & 18.5 & 23.9 & 24.6 & 24.7 \\
\hline
\end{tabular}

* Data are on dry weight basis.

Table 9. Effect of dietary Fe levels on proximate and mineral compositions of the liver of tiger puffer (Expt. II)*

\begin{tabular}{|c|c|c|c|c|c|}
\hline $\begin{array}{l}\text { Diet no. } \\
\text { (Dietary Fe, mg/kg) }\end{array}$ & $\begin{array}{c}3 \\
(55) \\
\end{array}$ & $\begin{array}{c}4 \\
(92) \\
\end{array}$ & $\begin{array}{c}5 \\
(140)\end{array}$ & $\begin{array}{c}6 \\
(197) \\
\end{array}$ & $\begin{array}{c}7 \\
(263) \\
\end{array}$ \\
\hline Moiture (\%) & 34.4 & 31.2 & 32.2 & 31.9 & 28.7 \\
\hline Crude protein (\%) & 4.2 & 6.2 & 6.8 & 6.4 & 6.0 \\
\hline Crude lipid (\%) & 85.4 & 88.6 & 86.4 & 87.4 & 90.5 \\
\hline Crude ash (\%) & 8.5 & 7.3 & 7.6 & 7.0 & 8.2 \\
\hline $\mathrm{Ca}(\%)$ & 24.8 & 29.3 & 31.6 & 34.2 & 32.0 \\
\hline $\mathrm{P}(\%)$ & 61.0 & 62.3 & 60.1 & 60.4 & 60.2 \\
\hline $\operatorname{Mg}(\%)$ & 29.9 & 39.8 & 43.7 & 45.6 & 42.3 \\
\hline $\mathrm{Fe}(\mu \mathrm{g} / \mathrm{g})$ & 5.0 & 10.3 & 13.1 & 12.6 & 11.8 \\
\hline $\mathrm{Zn}(\mu \mathrm{g} / \mathrm{g})$ & 8.0 & 8.9 & 11.0 & 9.4 & 8.7 \\
\hline
\end{tabular}

* Data are on dry weight basis.

the maximum values of UIBC and TIBC were detected in fish fed the $55 \mathrm{mg}$ Fe diet, while similar values of these parameters were found in other treatment groups except that TIBC tended to decrease with the increase of dietary Fe. Plasma $\mathrm{K}$ and Mg contents were slightly high in fish fed the diets containing $55 \mathrm{mg}$ and $92 \mathrm{mg} \mathrm{Fe} / \mathrm{kg}$, but plasma $\mathrm{Ca}$ and $\mathrm{P}$ contents were similar in all treatment groups. The minneral contents of vertebrae are shown in Table 8 . There were no differences in $\mathrm{Ca}, \mathrm{P}$, and $\mathrm{Mg}$ contents of vertebrae among the treatment groups, however, vertebral $\mathrm{Fe}, \mathrm{Zn}$, and $\mathrm{Mn}$ contents were slightly lower in fish fed the diets containing less than $140 \mathrm{mg} \mathrm{Fe} / \mathrm{kg}$ diet. Reduced liver Fe and $\mathrm{Mg}$ contents were also observed in fish fed the $55 \mathrm{mg}$ Fe diet (Table 9).

\section{DISCUSSION}

The present study demonstrated that dietary Fe deficiency induced hypochromemia in tiger puffer. Fe deficiency in tiger puffer was characterized by reduced $\mathrm{Hb}, \mathrm{Ht}, \mathrm{RBC}$, plasma and vertebral Fe, and ISI as reported for brook trout (Kawatsu, 1972), yellowtail (Ikeda at al., 1973), Japanese eel (Arai et al., 1975), red sea bream (Sakamoto and Yone, 1976, 1978a), carp (Sakamoto and Yone, 1978b), channel catfish (Gatlin and Wilson, 
1986), and Atlantic salmon (Anderson et al., 1996). In most fish species, growth and feed efficiency were not affected by Fe deficiency. However, Gatlin and Wilson (1986) and Lim and Klesius (1997) observed decreased growth and feed efficiency in channel catfish fed $\mathrm{Fe}$-deficient diets. In the present study, growth performances of $\mathrm{Fe}$-unsupplemented groups were different between the two experiments. The Fe level of the Fe-unsupplemented diet in experiment I was $19 \mathrm{mg} / \mathrm{kg}$ diet, but that in experiment II was $55 \mathrm{mg} / \mathrm{kg}$ diet due to the difference in the composition of the basal diets in experiments I and II. Therefore, Fe deficiency might be more severe in fish fed the diet containing the least amount of $\mathrm{Fe}$ as observed in experiment I. Furtheremore, it is possible that the difference in fish size affects the growth of fish in the present study, because, initial body weight of fish used in experiment I was smaller than that in experiment II. Poor growth was also observed in smaller size (17.5 g) of yellowtail but not in larger size ( $42 \mathrm{~g}$ ) of yellowtail (Makino et al., 1989; Iida et al., 1991). Based on the present study, the dietary Fe requirement of tiger puffer is considrered to be $90-140 \mathrm{mg} / \mathrm{kg}$ diet.

\section{ACKNOWLEDGEMENTS}

We wish to express our sincere thanks to the staffs of Fishery Research Laboratory, Kyushu University for their kind helps in conducting this research. This is the contribution no. 252 from Fishery Research Laboratory, Kyushu University.

\section{REFERENCES}

Anderson, F., A. Maage and K. Julshamn 1996 An estimation of dietary iron requirement of Atlantic salmon, Salmo Salar L., parr. Aquacult. Nutr., 2: 41-47

Arai, S., H. Kawatsu, T. Nose and Y. Hashimoto 1975 Mineral requirement of Japanese eel-II. Iron requirement. Abstract of April Meeting in Japanese Society of Fisheries Science, pp. 48 (in Japanese)

El-Zibdeh, M., T. Yoshimatsu, S. Matsui, M. Furuichi, C. Kitajima and R. Azuma 1995 Requirement of redlip mullet for dietary phosphorus. J. Fac. Agr., Kyushu Univ., 40: 135-145

Gatlin, D. M., III and R. P. Wilson 1986 Characterization of iron deficiency and the dietary iron requirement of fingerling channel catfish. Aquaculture, 52: 191-198

Halver, J. E. 1957 Nutrition of salmonid fishes. III. Water-soluble vitamin requirements of chinook salmon. J. Nutr., 62: 225-243

lida, S., T. Iwamoto, H. Hosokawa, S. Shimeno and M. Ukawa 1991 Iron requirement of yellowtail. Abstract of April Meeting in Japanese Society of Fisheries Science, pp. 44 (in Japanese)

Ikeda, Y., H. Ozaki and K. Uematsu 1973 Effect of enriched diet with iron in culture of yellowtail. $J$. Tokyo Univ. Fish., 59: 91-99

Kawatsu, H. 1972 Studies on the anemia of fish. V. Dietary iron deficient anemia in brook trout, Salvelinus fontinalis. Bull. Freshwater Fish. Res. Lab., 22: 59-67

Lim, C. and P. H. Klesius 1997 Responses of channel catfish (Ictaluris punctatus) fed iron-deficient and replete diets to Edwardsiella ictaluri challenge. Aquaculture, 157: 83-93

Makino, H., S. Iida, H. Hosokawa and M. Takeda 1989 Necessity of dietary minerals in yellowtail. Abstract of April Meeting in Japanese Society of Fisheries Science, pp. 43 (in Japanese)

Sakamoto, S. and Y. Yone 1976 Requirement of red sea bream for dietary Fe-I. Rep. Fish. Res. Lab., Kyushu Univ., 3: 53-58

Sakamoto, S. and Y. Yone 1978a Requirement of red sea bream for dietary iron-II. Nippon Suisan Gakkaishi, 44: 223-225

Sakamoto, S. and Y. Yone 1978b Iron deficiency symptoms of carp. Nippon Suisan Gakkaishi, 44: 1157-1160 